\title{
Keragaman Daerah Kontrol DNA Mitokondria Rusa Timor (Cervus timorensis timorensis) di Pulau Timor, Alor, dan Pantar
}

\author{
Mitochondrial Control Region Diversity of the Timor Deer (Cervus timorensis timorensis) \\ in Timor, Alor, and Pantar Islands
}

\section{Syamsul Arifin Zein}

Pusat Penelitian Biologi, Lembaga Ilmu Pengetahuan Indonesia, Cibinong Sciences Centre

E-mail: zein_genetic@yahoo.com

\begin{abstract}
A study on mtDNA control region diversity of the timor deer was conducted in East Nusa Tenggara Province. Sample consisted of 20 individuals from 3 islands (Timor, Pantar, and Alor). Total DNA were extracted from leucocyte (buffy coat). Fragment control region of the mitochondrial DNA were amplified by Polymerase Chain Reaction (PCR) using primers of forward primer 5"AAACCAGAAAAGGAGAGCAAC3" and reverse primer 5"TCATCTAGGCATTTTCAGTGCC3". Nucleotide sequence of the mitochondrial control region were aligned by using ClastalX and phylogenetic analyses by NeighborJoining methode. Kimura two-parameter model of nucleotide substitution using pairwise distance calculation program was implemented with the Mega software version 3. The purposes of this study, were to examine the control region (D-Loop) of the mitochondrial DNA and to discuss the phylogeography of the Cervus timorensis timorensis in East Nusa Tenggara Province. Results indicated that from 435 base nucleotide sequences, 16 polymorphic sites with 8 haplotypes were found among 3 islands. Haplotype diversity and nucleotide diversity were 0.056 and 0.039 . DNA distances values ranged from 0.014 to 0.021 .
\end{abstract}

Key words: Cervus timorensis timorensis, mitochondrial DNA, region diversity

Diterima: 09 Februari 2007, disetujui: 21 Agustus 2007

\section{Pendahuluan}

Rusa timor sebagai salah satu
representatif
spesies rusa di Indonesia,
diklasifikasikan sebagai spesies dilindungi. Rusa timor sering disebut rusa jawa merupakan salah satu jenis mamalia yang termasuk dalam ordo Artiodactyla, subordo Ruminansia, infraordo Pecora, famili Cervidae, dan genus Cervus. Berdasarkan karakter warna dan ukuran tubuh menurut Whitehead (1972), rusa timor mempunyai delapan subspesies. Subspesies Cervus timorensis timorensis sebarannya meliputi pulau Timor, Roti, Semau, Kambing, Alor, Pantar, dan pulau Rusa (Bemmel, 1949), di Propinsi Nusa Tenggara
Timur. Populasi rusa ini dilaporkan cenderung turun, oleh sebab itu perlu diamati secara sistematis dan berkesinambungan, agar potensi sumber daya hayati ini dapat dikembangkan secara optimal (Zein \& Saim, 2001). Perburuan liar dan rusaknya habitat dilaporkan sebagai penyebab utama terjadi penurunan populasi rusa di Propinsi Nusa Tenggara Timur. Oleh karena itu keberhasilan mempertahankan populasi rusa ini tergantung dari pengelolaan daerah konservasi (Sutrisno, 1993).

Kajian keragaman genetik populasi satwa pada tingkat molekuler perlu dilakukan, karena mempunyai implikasi yang penting terhadap keberlangsungan hidup populasi satwa di daerah konservasi (Zein \& Maharadatunkamsi, 2003). 
Penelitian keragaman genetik rusa timor terhadap daerah kontrol dengan metode RFLP telah dilakukan oleh Syafitri (2004) menggunakan enzim restriksi HaeIII (GG $\downarrow \mathrm{CC}), H a p \mathrm{II}(\mathrm{C} \downarrow \mathrm{CGG}), A l u \mathrm{I}$ (AG $\downarrow \mathrm{CT})$, $R s a \mathrm{I}(\mathrm{GT} \downarrow \mathrm{AC}) \operatorname{BamHI}(\mathrm{G} \downarrow \mathrm{GATCC})$, dan EcoRI (G $\downarrow$ AATTC). Hasil penelitian ini tidak dapat mendeteksi adanya keragaman terhadap sampel rusa yang dikoleksi dari pulau Timor, Alor, Pantar, Taman Nasional Rawa Aopa (Sulawesi Tenggara), dan koleksi Kebun Binatang Ragunan. Hal ini menunjukkan metode PCRRFLP memerlukan enzim restriksi yang jauh lebih banyak untuk mendeteksi keragaman genetik. Oleh karena itu perlu dilakukan penelitian dengan penanda molekuler lainnya, seperti daerah kontrol dari DNA mitokondria.

Kajian satwa liar telah banyak mengunakan genom DNA mitokondria. Genom DNA mitokondria diwariskan secara maternal dan memiliki laju mutasi hingga 10 kali lebih cepat dibandingkan DNA inti (Zein et al., 1998; Hishe et al., 1998; Zein \& Maharadatunkamsi, 2003). Oleh sebab itu digunakan secara luas dalam mempelajari evolusi, struktur populasi, aliran gen, hibridisasi, biogeografi, dan filogenetik (Moritz et al., 1987). Sebagian besar genom DNA mitokondria binatang mempunyai ukuran sekitar 16.000-18.000 pasang basa, terdiri dari 13 gen penyandi kode protein, 22 gen transfer RNA, 2 gen ribosomal RNA, dan sebuah daerah kontrol. Mamalia mempunyai daerah kontrol yang terletak diantara gen tRNA $^{\text {Pro }}$ dan gen tRNA $^{\text {Phe }}$ (Wilkinson \& Chapman, 1991).

Daerah kontrol (D-Loop) merupakan daerah non-coding pada DNA mitokondria metazoa yang dibagi menjadi tiga bagian, yaitu 5-(left) pheriferal domain, central conserved region, dan 3-(right) pheriferal domain. Daerah central conserved region diketahui mempunyai urutan nukleotida antarspesies dengan tingkat kesamaan yang tinggi (Brown et al., 1986). Sedangkan dibagian 5-(left) pheriferal domain dan 3-(right) pheriferal domain menunjukkan urutan DNA dengan tingkat keragaman yang tinggi (Mignotte et al., 1987). Selain itu, daerah kontrol digunakan secara luas dalam kajian populasi dan evolusi genetik pada mamalia(Douzery \& Randi, 1997).
Daerah kontrol merupakan bagian genom mitokondria yang bersifat hipervariabel. Analisis keragaman genetika pada daerah yang bersifat spesifik tersebut memungkinkan untuk digunakan sebagai penanda genetika dan dapat mengungkapkan adanya perbedaan intraspesies rusa timor secara filogeografi dan mengetahui hubungan kekerabatannya (Wilkinson \& Chapman, 1991; Brown et al., 1986). Pada penelitian ini akan digunakan sekuen urutan nukleotida fragmen daerah kontrol DNA mitokondria untuk memberikan gambaran yang lebih jelas tentang diversitas populasi rusa di pulau Timor, Pantar, dan Alor.

\section{Metode Penelitian}

\section{Bahan DNA}

Bahan DNA yang digunakan berupa sel darah putih (buffy coat) sebagai sumber isolasi DNA. Sampel sebanyak 20 individu, dari rusa hasil tangkapan warga lokal di sekitar habitatnya di pulau Timor (13), Alor (5), dan Pantar (3). Pengambilan sampel darah dilakukan dengan menangkap rusa dari dalam kandang terbuka dengan menggunakan tali, kemudian dibius dengan Ileum Xylazil-20 (Troy Laboratories Pty, Limited) berisi Xylazine$20 \mathrm{mg} / \mathrm{ml}$. Dosis yang digunakan adalah $3 \mathrm{mg} / \mathrm{kg}$ berat badan rusa. Pengambilan darah dilakukan dari vena jugularis dengan menggunakan alat suntik $10 \mathrm{ml}$ yang telah dibasahi anti koagulan (heparin).

Sampel darah dipisahkan bagian plasma, leukosit/sel darah putih (buffy coat), dan eritrosit/sel darah merah dengan cara sentrifugasi 4000 rpm selama 15 menit. Leukosit (buffy coat) mamalia mengandung inti sel disimpan di dalam kotak es selama berada di lapangan, sedangkan plasma darah dan eritrosit (sel darah merah) disimpan tersendiri untuk keperluan analisis yang lain. Selanjutnya ekstraksi dan purifikasi DNA, PCR serta analisis sekuensing dilakukan di laboratorium genetika, Bidang Zoologi, Pusat Penelitian Biologi-LIPI.

\section{Ekstraksi dan purifikasi}

Ekstraksi dan purifikasi DNA total dari leukosit/sel darah putih (buffy coat) dilakukan dengan menggunakan metode dialisis (Kan et 
al., 1977). Hasil ekstraksi dan purifikasi DNA total disimpan pada temperatur $4^{\circ} \mathrm{C}$ sampai digunakan untuk keperluan analisis, sedangkan untuk penyimpanan jangka panjang material DNA disimpan di dalam freezer $\left(-20^{\circ} \mathrm{C}\right)$.

\section{Kajian daerah kontrol DNA mitokondria}

Analisis keragaman genetik dalam penelitian menggunakan fragmen daerah kontrol dari DNA mitokondria. Amplifikasi fragmen tersebut menggunakan primer spesifik untuk rusa yang terletak di tRNA ${ }^{\text {Thr }}$ (forward primer) dan $\mathrm{tRNA}^{\text {Phe }}$ (reverse primer). Primer DNA untuk mengamplifikasi daerah kontrol dirancang oleh Soerjobroto (Komunikasi pribadi) berdasarkan hasil sekuen rusa merah (Cervus elephus) (Douzery \& Randi, 1997). Primer tersebut adalah sebagai berikut: forward primer 5"AAACCAGAAAAGGAGAGCAAC3" dan reverse primer 5"TCATCTAGGCATTTT CAGTGCC3".

Amplifikasi daerah kontrol dengan PCR (Polymerase Chain Reaction) menggunakan mesin Thermal Cycler Type 9600 (Perkin Elmer). Campuran reaksi PCR dibuat sebanyak $50 \mu$ dengan komposisi: 40 ng sampel DNA; 1xPCR buffer (Amersham Pharmacia Biotech Inc), 0,2 mM dNTP (Amersham Pharmacia Biotech Inc), 10 pmol masing-masing primer, dan 1,25 unit tag polymerase (Amersham Pharmacia Biotech Inc). Hasil amplifikasi disaring menggunakan MicroSpin ${ }^{\mathrm{TM}} \mathrm{S}-400 \mathrm{HR}$ Columns (Amersham Pharmacia Biotech Inc).

\section{Analisis sekuensing}

Sekuensing daerah kontrol dilakukan sebagian (partial) sekitar 435 urutan basa menggunakan Alfexpress DNA Sequencer (pharmacia Biotech). Kit reagen yang digunakan adalah Thermo sequennase fluorescent labelled primer cycle sequensing kit (Amersham Pharmacia Biotech). Multiple alignment urutan basa hasil sekuen DNA menggunakan program ClustalX. Analisis filogenetik menggunakan metode neighbor-joining. Kalkulasi matrik jarak genetik dilakukan menggunakan model Kimura-2 parameter yang diimplementasikan pada pairwise distance calculation dalam program Mega (Molecular Evolutionary Genetics Analysis) software Versi 3 (Kumar et al., 2004). Keragaman haplotipe (haplotype diversity) dihitung dengan rumus $1-\Sigma \mathrm{pi}^{2}$ dengan p adalah frekuensi dari haplotipe ke $i$, sedangkan keragaman nukleotida (nucleotide diversity) adalah jumlah situs yang polimorfik dari spesimen dari suatu lokasi, dibagi jumlah urutan sekuen DNA yang dievaluasi (Hartl \& Clark, 1989).

\section{Hasil dan Pembahasan}

\section{Amplifikasi daerah kontrol}

Kondisi optimal dalam amplifikasi daerah kontrol dengan mesin Thermal Cycler Type 9600 (Perkin Elmer), yaitu: predenaturasi $95^{\circ} \mathrm{C}$ selama 5 menit, sedangkan denaturasi, hibridisasi primer, dan elongasi berturut-turut sebagai berikut $95^{\circ} \mathrm{C}$ selama 30 detik, $60^{\circ} \mathrm{C}$ selama 30 detik, $72^{\circ} \mathrm{C}$ selama 1 menit dengan siklus amplifikasi sebanyak 40 kali. Selain itu ditambahkan pasca elongasi dengan temperatur $72^{\circ} \mathrm{C}$ selama 10 menit.

\section{Variasi sekuen DNA}

Analisis daerah kontrol DNA mitokondria adalah untuk mengetahui tingkat keragaman genetik berdasarkan variasi urutan sekuen DNA rusa timor (Cervus timorensis timorensis) di pulau Timor, Pantar, dan Alor di Propinsi Nusa Tenggara Timur. Variasi dari urutan sekuen DNA daerah kontrol akan dapat memberikan gambaran yang meliputi jumlah haplotipe, frekuensi haplotipe, keragaman haplotipe, keragaman nukleotida, dan rekonstruksi pohon filogenetik.

Multiple alignment sekitar 435 urutan basa daerah kontrol dari 20 individu sekuen rusa timor menemukan 16 situs polimorfik dan terdapat 8 tipe sekuen (haplotipe), yaitu haplotipe A, B, C, D, E, F, G, dan H (Tabel 1) dan dibandingkan dengan sekuen referensi (GenBank accession number AF2918 83). Sebaran haplotipe tersebut adalah di pulau Timor sebanyak tujuh haplotipe (A, B, C, D, E, G, dan H), pulau Pantar satu haplotipe (A), dan pulau Alor dua haplotipe (A dan F). Frekuensi haplotipe $\mathrm{A}$ di seluruh pulau adalah 0,65, sedangkan haplotipe $\mathrm{B}, \mathrm{C}, \mathrm{D}, \mathrm{E}, \mathrm{F}, \mathrm{G}$, dan H frekuensinya sama yaitu 0,05 (Tabel 2).

Hal ini menunjukkan frekuensi haplotipe merata pada haplotipe $\mathrm{B}, \mathrm{C}, \mathrm{D}, \mathrm{E}, \mathrm{G}$, dan $\mathrm{H}$, 
tetapi sangat berbeda jika dibandingkan dengan haplotipe A. Selain itu, haplotipe A dominan di pulau Timor dan menyebar lebih luas di semua pulau yaitu Timor, Pantar, dan Alor. Hal ini mengindikasikan belum terjadinya divergensi genetik di antara populasi rusa di masingmasing pulau yaitu pulau Timor, Pantar, dan Alor. Namun demikian untuk memperkuat temuan ini diperlukan sampel yang lebih banyak untuk tiap populasinya.

Hal ini juga dilaporkan Zein et al., (1998), hasil analisis dengan metode RFLP (Restriction Fragment Length Polymorphism) terhadap fragmen dari gen 12SrRNA dengan menggunakan enzim restriksi HaeIII dan Mbo 1 diketahui terdapat dua haplotipe pertama terdapat di pulau Timor, Alor, dan Pantar, sedangkan haplotipe kedua terdapat di pulau Timor, Semau, dan Alor. Menurut Avise (1994), populasi-populasi yang jelas memperlihatkan struktur dan divergensi genetik pada umumnya telah mengalami proses pemisahan cukup lama. Jika hal ini terjadi umumnya ditunjukkan dengan terputusnya aliran gen.
Perburuan liar dan fragmentasi habitat di Nusa Tenggara Timur dilaporkan telah mengakibatkan populasi rusa timor terus menurun (Sutrisno, 1993). Hal ini menyebabkan peningkatan laju genetic drift. Selain itu, populasi yang kecil cenderung akan terjadi kawin silang dalam (inbreeding). Ketiga hal tersebut dapat berdampak buruk terhadap kelangsungan hidup dari populasi rusa yang ada. Indikasinya adalah turunnya keragaman genetik dalam populasi, yaitu turunnya keragaman haplotipe dan keragaman nukleotida. Adanya penurunan variabilitas genetik ini dapat membahayakan kelangsungan hidup populasi karena dapat mengurangi kemampuan individual dalam menghadapi tekanan seleksi alamiah, terutama akibat perubahan lingkungan (Avise, 1994; Lande \& Barrowclough, 1987; Hartl, 2000; Hedrick, 2000). Dengan demikian, upaya konservasi selayaknya diarahkan untuk menghentikan laju penurunan keragaman genetika.

Tabel 1. Polimorfisme nukleotida yang dianalisis pada segmen daerah kontrol dari DNA mitokondria dibandingkan dengan referensi Genbank dengan nomor akses AF291883 (NCBI)

\begin{tabular}{|c|c|c|c|c|c|c|c|c|c|c|c|c|c|c|c|c|}
\hline Nomor urut daerah & $\mathbf{1}$ & 1 & $\mathbf{1}$ & 1 & 2 & 2 & 2 & 2 & 2 & 2 & 2 & 3 & 3 & 3 & 3 & 4 \\
\hline kontrol dari DNA & 3 & 5 & 7 & 9 & $\mathbf{0}$ & 1 & 4 & 4 & 7 & 8 & 9 & 4 & 7 & 7 & 8 & 1 \\
\hline mitokondria & 8 & 3 & 6 & 9 & 8 & 7 & 2 & 7 & 1 & 7 & $\mathbf{0}$ & 5 & 2 & 9 & 2 & 1 \\
\hline AF291883(NCBI) & G & $\mathrm{T}$ & $\mathrm{T}$ & $\overline{\mathrm{A}}$ & $\mathrm{C}$ & $\bar{G}$ & $\mathrm{~T}$ & $\mathrm{C}$ & A & $\mathrm{C}$ & $\mathrm{T}$ & G & $\mathrm{C}$ & A & $\mathrm{C}$ & $\mathrm{C}$ \\
\hline Haplotipe A & A & $\mathrm{T}$ & $\mathrm{T}$ & A & $\mathrm{C}$ & G & $\mathrm{C}$ & $\mathrm{C}$ & A & $\mathrm{C}$ & A & A & $\mathrm{T}$ & $\mathrm{T}$ & $\mathrm{T}$ & $\mathrm{C}$ \\
\hline HaplotipeB & A & $\mathrm{T}$ & $\mathrm{T}$ & A & $\mathrm{C}$ & $\mathrm{C}$ & $\mathrm{T}$ & $\mathrm{C}$ & A & $\mathrm{C}$ & A & A & $\mathrm{T}$ & $\mathrm{T}$ & $\mathrm{T}$ & $\mathrm{C}$ \\
\hline HaplotipeC & A & $\mathrm{T}$ & $\mathrm{T}$ & A & $\mathrm{C}$ & G & $\mathrm{T}$ & $\mathrm{C}$ & A & $\mathrm{C}$ & A & A & $\mathrm{T}$ & $\mathrm{T}$ & $\mathrm{T}$ & $\mathrm{C}$ \\
\hline HaplotipeD & A & $\mathrm{T}$ & G & A & $\mathrm{C}$ & G & $\mathrm{C}$ & $\mathrm{C}$ & A & $\mathrm{C}$ & A & A & $\mathrm{T}$ & $\mathrm{T}$ & $\mathrm{T}$ & $\mathrm{C}$ \\
\hline HaplotipeE & A & G & $\mathrm{T}$ & A & $\mathrm{C}$ & G & $\mathrm{C}$ & $\mathrm{C}$ & A & $\mathrm{C}$ & A & A & $\mathrm{T}$ & $\mathrm{T}$ & $\mathrm{T}$ & $\mathrm{C}$ \\
\hline HaplotipeF & A & $\mathrm{T}$ & $\mathrm{T}$ & $\mathrm{T}$ & $\mathrm{C}$ & G & $\mathrm{C}$ & $\mathrm{C}$ & A & $\mathrm{C}$ & A & A & $\mathrm{T}$ & $\mathrm{T}$ & $\mathrm{T}$ & C \\
\hline HaplotipeG & A & $\mathrm{T}$ & $\mathrm{T}$ & A & $\mathrm{C}$ & G & $\mathrm{C}$ & $\mathrm{C}$ & G & $\mathrm{C}$ & A & A & $\mathrm{T}$ & $\mathrm{T}$ & $\mathrm{T}$ & A \\
\hline HaplotipeH & G & $\mathrm{T}$ & $\mathrm{T}$ & A & G & G & G & G & A & G & A & A & $\mathrm{T}$ & $\mathrm{T}$ & $\mathrm{T}$ & C \\
\hline
\end{tabular}

Tabel 2. Frekuensi haplotipe, keragaman haplotipe, dan keragaman nukleotida gen daerah kontrol dari DNA mitokondria

\begin{tabular}{|c|c|c|c|c|c|c|c|c|c|c|c|}
\hline \multirow[t]{2}{*}{ No. } & \multirow[t]{2}{*}{ Lokasi } & \multicolumn{8}{|c|}{ Frekuensi Haplotipe } & \multirow{2}{*}{$\begin{array}{c}\text { Keragaman } \\
\text { Haplotipe }\end{array}$} & \multirow{2}{*}{$\begin{array}{l}\text { Keragaman } \\
\text { Nukleotida }\end{array}$} \\
\hline & & $\mathbf{A}$ & B & $\mathbf{C}$ & D & $\mathbf{E}$ & $\mathbf{F}$ & G & $\mathbf{H}$ & & \\
\hline$\overline{11}$ & $\overline{\mathrm{T} T}$ & 0,57 & 0,07 & 0,07 & 0,07 & 0,07 & - & 0,07 & 0,07 & 0,5575 & 0,037 \\
\hline 2 & A & 0,80 & - & - & - & - & 0,20 & - & - & 0 & 18 \\
\hline 3 & Pantar & 1 & - & - & - & - & - & - & - & 0,32000 & 0,016 \\
\hline & Total & 0,65 & $\mathbf{0 . 0 5}$ & 0,05 & 0,05 & 0,05 & 0,05 & 0,05 & 0,05 & 0,056 & 0,039 \\
\hline
\end{tabular}


Hasil analisis menunjukkan bahwa 8 haplotipe yang teridentifikasi pada 16 situs polimorfik (polymorphic site) dan distribusi variasi sekuen dapat lihat di histogram pada Gambar 2. Distribusi tersebut menunjukkan bahwa sekuen dari fragmen daerah kontrol dari DNA mitokondria terdapat variasi pada urutan basa antara 100-150 (6,25\%), 151-200 (25\%), 201-250 (18,75\%), 251-300 (18,75\%), 301-350 $(6,25 \%), \quad 351-400 \quad(18,75 \%)$, dan $401-450$ $(6,25 \%)$. Hasil tersebut memperlihatkan bahwa daerah yang paling banyak terdapat situs polimorfik pada fragmen daerah kontrol dari DNA mitokondria adalah urutan basa sekitar 151-300 (18,7-25\%) dan urutan basa sekitar $351-400(18,75 \%)$.

Keragaman haplotipe yang terdapat di pulau Timor, Alor, dan Pantar berkisar antara 0-0,5575, sedangkan keragaman haplotipe tertinggi berada di pulau Timor yaitu 0,5575. Parameter yang umum digunakan untuk menggambarkan variasi genetika adalah keragaman nukleotida. Keuntungan menggunakan parameter ini adalah tidak tergantung pada besarnya sampel dan panjang DNA (Hartl \& Clark, 1989). Nei (1987) menyatakan bahwa besarnya keragaman nukleotida berdasarkan publikasi yang ada umumnya bervariasi antara 0,002 sampai 0,019 lebih kecil dari pada penelitian yang keragaman nukleotida menggunakan fragmen daerah kontrol sepanjang 435 urutan basa adalah 0,016-0,037 dan yang tertinggi berada di pulau Timor yaitu 0,037. Keragaman nukleotida di semua pulau yang diteliti, yaitu pulau Timor, Alor, dan Pantar adalah 0,039 lebih besar dibandingkan Zein dan Maharadatunkamsi (2003) yang melakukan penelitian pada kelelawar pemakan buah (Chironax melanocephalus), keragaman nukleotida dari 355 urutan basa gen 12SrRNA adalah 0,0027 sampai 0,0166. Hal ini menunjukkan keragaman nukleotida daerah kontrol dari DNA mitokondria dari rusa timor di pulau Alor, Pantar, dan Timor lebih tinggi (Tabel 2).

Hasil penelitian ini menunjukkan bahwa frekuensi haplotipe, keragaman haplotipe, dan keragaman nukleotida terbesar berada di pulau Timor. Berarti keragaman genetika rusa timor di pulau Timor masih tinggi. Informasi frekuensi haplotipe, keragaman haplotipe, dan keragaman nukleotida sangat penting untuk memprediksi keadaan populasi rusa di kawasan konservasi. Aplikasi penanda DNA ini akan memberi kesempatan lebih jelas dalam mengamati struktur populasi. Hal ini disebabkan analisis DNA merupakan indikator yang akurat untuk melihat dinamika dan struktur populasi (Avise et al., 1987; Hishe et al., 1998).

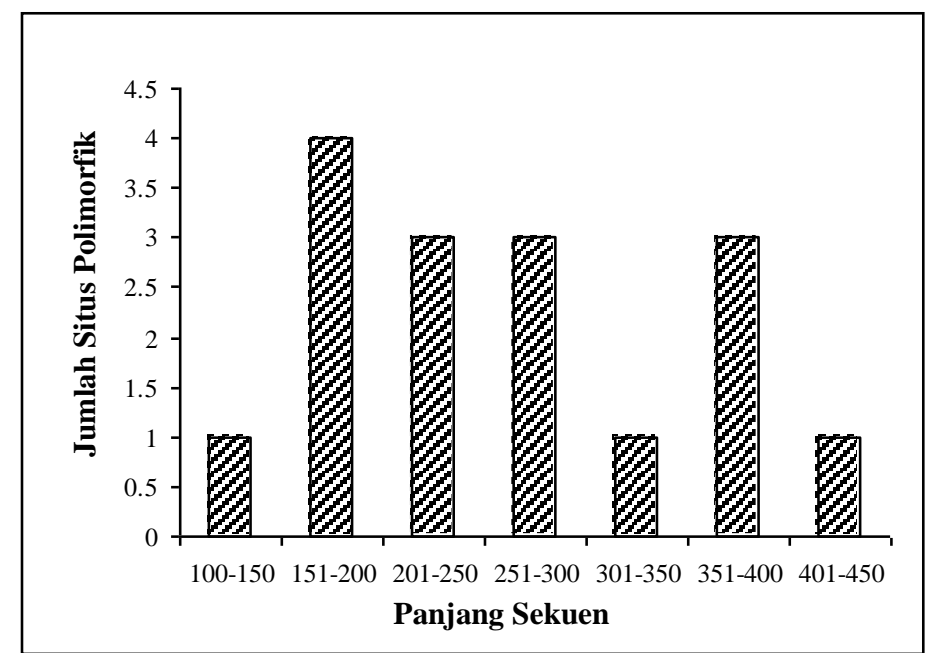

Gambar 2. Distribusi variasi sekuen pada segmen DNA mitokondria rusa timor 
Jarak genetika diantara haplotipe A, B, $\mathrm{C}, \mathrm{D}, \mathrm{E}, \mathrm{F}$, dan $\mathrm{G}$ dibandingkan dengan sekuen AF291883 (NCBI) berkisar anatara 0,014 0,021 . Jarak genetika yang paling jauh adalah haplotip H dan G $(0,021)$, D dan F $(0,019)$, A, E, dan B $(0,017)$ serta $C$ yang paling dekat yaitu 0,014 (Tabel 3). Gambaran lebih jelas dapat dilihat pada rekonstruksi pohon filogeni dengan menggunakan metode Neighborjoining (Gambar 3). Metode neighbor-joining (NJ) seperti metode lainnya yang termasuk dalam metode jarak, merupakan suatu metode yang didasari pada prinsip pengelompokkan taksa berdasarkan nilai jarak evolusioner pasangan-pasangan operational taxonomy unit dimana setiap percabangan yang terdapat dalam pohon filogenetik berevolusi pada kecepatan dan taraf yang tidak sama (Hartl, 2000).

Rekonstruksi pohon filogenetik sejumlah populasi rusa timor dilakukan berdasarkan data urutan nukleotida daerah kontrol dari DNA mitokondria. Daerah kontrol merupakan daerah tak menyandi (non-coding region), sehingga daerah tersebut memiliki kecepatan evolusi yang lebih tinggi dibandingkan daerah lainnya (Taberlet, 1996). Dengan demikian, daerah kontrol memiliki lebih banyak situs polimorfik yang berguna dalam rekonstruksi filogenetik intraspesifik.

\section{Kesimpulan}

Hasil analisis keragaman genetik rusa timor di pulau Timor, Alor, dan Pantar diketahui terdapat delapan haplotipe. Keragaman haplotipe berkisar antara 0-0,5575. Keragaman nukleotida sebesar 0,016 - 0,037. Jarak genetik antara $0.014-0.021$. Rusa timor di Pulau Timor, Pantar, dan Alor mengindikasikan masih adanya aliran gen dan keragaman genetik cukup tinggi. Dengan demikian populasi rusa timor di pulau-pulau tersebut dapat dikelola sebagai satu kesatuan unit manajemen.

Tabel 3. Estimasi matrik jarak genetik rusa timor (Cervus timorensis timorensis) di pulau Timor, Pantar, dan Alor dengan Mega versi 3

\begin{tabular}{lccccccccc}
\hline \hline & $\mathbf{1}$ & $\mathbf{2}$ & $\mathbf{3}$ & $\mathbf{4}$ & $\mathbf{5}$ & $\mathbf{6}$ & $\mathbf{7}$ & $\mathbf{8}$ & $\mathbf{9}$ \\
\hline \hline Haplotipe D & 0,000 & & & & & & & & \\
Haplotipe A & 0,002 & 0,000 & & & & & & & \\
Haplotipe G & 0,007 & 0,005 & 0,000 & & & & & & \\
Haplotipe F & 0,005 & 0,002 & 0,007 & 0,000 & & & & & \\
Haplotipe E & 0,005 & 0,002 & 0,007 & 0,005 & 0,000 & & & & \\
Haplotipe B & 0,007 & 0,005 & 0,009 & 0,007 & 0,007 & 0,000 & & & \\
Haplotipe C & 0,005 & 0,002 & 0,007 & 0,005 & 0,005 & 0,002 & 0,000 & & \\
Haplotipe H & 0,014 & 0,012 & 0,016 & 0,014 & 0,014 & 0,014 & 0,012 & 0,000 & \\
AF291883 & 0,019 & 0,017 & 0,021 & 0,019 & 0,019 & 0,017 & 0,014 & 0,021 & 0,000 \\
\hline \hline
\end{tabular}

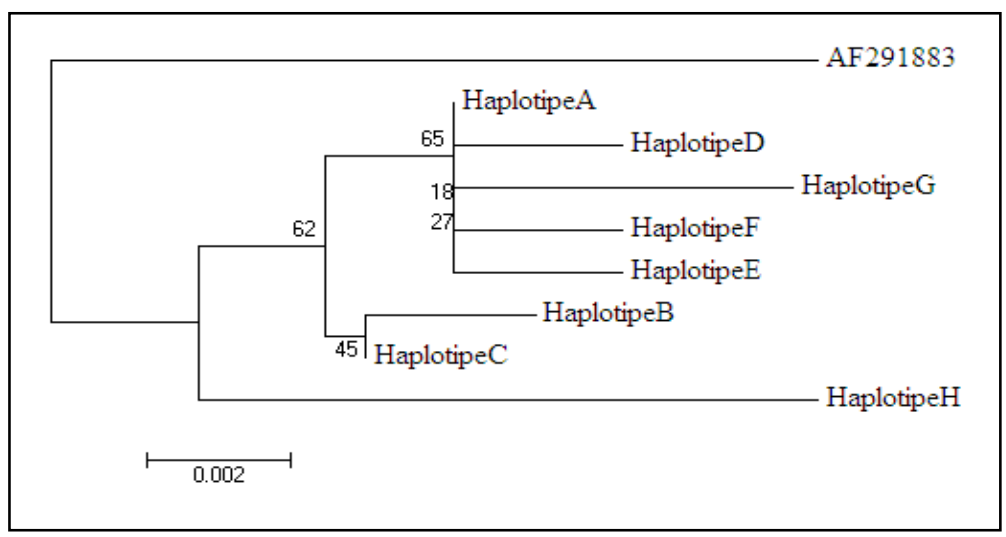

Gambar 3. Rekonstruksi pohon filogenetik rusa timor dari haplotipe A, B, C, D, E, F, G, dan H, dengan metode Neighbor-joining menggunakan Mega Software versi 3.0 


\section{Ucapan Terima Kasih}

Ucapan terima kasih kepada BKSDA Kupang, Dr. Bambang Surjobroto (IPB), Dr. Sri Sulandari, Ir. Maharadatunkamsi, M.Sc., serta Agus Kundarmasno yang telah banyak membantu penulis.

\section{Daftar Pustaka}

Bemmel, A.C.V. 1949. Revision of the rusine deer in the Imdo-Australian Archipelago. Treubia 20: 191.

Brown, G.G., Gadaleta, G., Pepe, G., Saccone, C. and Sbisa, E. 1986. Structural conservation and variation in the D-Loop containing region of vertebrate mitochondrial DNA. J. Mol. Biol. 192: 503-511.

Douzery, E. and Randi, E. 1997. The mitochondrial control region of Cervidae: evolutionary patterns and phylogenetic content. Mol. Biol. Evol. 14 (11): 1154-1166.

Hartl, D.L. 2000. A primer of population genetics. 3rd ed. Sinauer Associates, Inc., Sunderland: xvii + $221 \mathrm{hlm}$.

Hartl, D.L. and Clark, A.G. 1989. Principles of population genetics, $2^{\text {nd }}$ ed. Sinauer Associates, Massachusetts.

Hedrick, P.W. 2000. Genetics of populations. 2nd ed. Jones and Bartlett Publishers, Sudbury: xv + $553 \mathrm{hlm}$.

Hishe, S., Westerman, M. and Schmitt, L.H. 1998. Biogeography of the Indonesian Archipelago: mitochondrial DNA variation in the fruit bat, Eonycteris spelaea. J. Linn. Soc. 65: 329-345.

Kan, Y.W., Dozy, A.M., Trecartin, R. and Tod, D. 1977. Identification of nondeletion in $\alpha$ Thalassemia. N. Engl. J. Med. 297: 10811084.

Kumar, S., Tamara, K. and Nei, M. 2004. Mega3: Integrated software for molecular Evolutionar genetics analysis and sequence alignment. Briefings in Bioinformatics. 5 (2): 150-163.

Lande, R. and Barrowclough, G.F. 1987. Effective population size, genetic variation, and their use in population management. In: Soule, M.E. (Eds.). Viable population for conservation, pp. 87-123. Cambridge University Press, Cambridge.
Mignotte, F., Guiride, F., Champagne, A.M. and Mounolou, J.C. 1990. Direct repeats in the noncoding region of rabbit mitochondrial DNA: involvement in the generation of intra and inter-individual heterogeneity. Eur. J. Biochem. 194: 561-571.

Moritz, C., Dowling, T.E. and Brown, W.M. 1987. Evolution of animal mitochondrial DNA: Relevance for population biology and systematics. Ann. Rev. Ecol. Syst. 18: 269-92.

Nei, M. 1987. Molecular Evolutionary Genetics. Columbia University Press, New York.

Sutrisno, E. 1993. Population Ecology of the Javan Deer (Cervus timorensis) in Menipo Island, East Nusa Tenggara. Indonesia. Thesis. University of the Philippines. Los Banos.

Syafitri, S. 2004. Keragaman Fragmen DNA Mitokondria daerah D-Loop Rusa Timor (Cervus timorensis) Asal Jawa, Sulawesi Tenggara dan Nusa Tenggara Timor. Skripsi. Fakultas MIPA, Institut Pertanian Bogor.

Taberlet, P. 1996. The use of mitochondrial DNA control region sequencing in conservation genetics. In: Smith, T.B. and Wayne, R.K. (Eds.). Molecular genetic approaches in conservation, pp. 125-142. Oxford University Press, New York.

Whitehead, G.K. 1972. Deer of the word. Constable. London.

Wilkinson, G.S. and Chapman, A.M. 1991. Length and sequence variation in evening bat D-Loop mtDNA. Genetics 128: 607-617.

Zein, M.S.A., Surjobroto, B., Durjadi, D. and Prijono, S.N. 1998. Study on characteristic of genetic of the Timor Deer (Cervus timorensis timorensis Blanville, 1822) in East Nusa Tenggara Province. Berita Biologi 4 (4): 117 125 .

Zein, M.S.A. dan Saim, A. 2001. Populasi, Pola Pertumbuhan, dan Ektoparasit Rusa Timor (Cervus timorensis macassaricus Heude, 1896) di Padang Savana Taman Nasional Rawa Aopa Watumohai, Propinsi Sulawesi Tenggara. Biota VI (1): 9-16.

Zein, M.S.A. dan Maharadatunkamsi. 2003. Analisis Gen 12SrRNA dari DNA Mitokondria Kelelawar Pemakan Buah Chironax melanocephalus (Chiroptera: Pteropodidae) di Taman Nasional Gunung Halimun. Biota VIII (1): 17-26. 